\title{
No to distance education! Production of meaning of discourses of nursing representative entities
}

\author{
Educação a distância, não! Produção de sentidos dos discursos de entidades representativas da enfermagem
}

¡Educación a distancia, no! Producción de sentidos significativos a partir de entidades representantes de enfermería

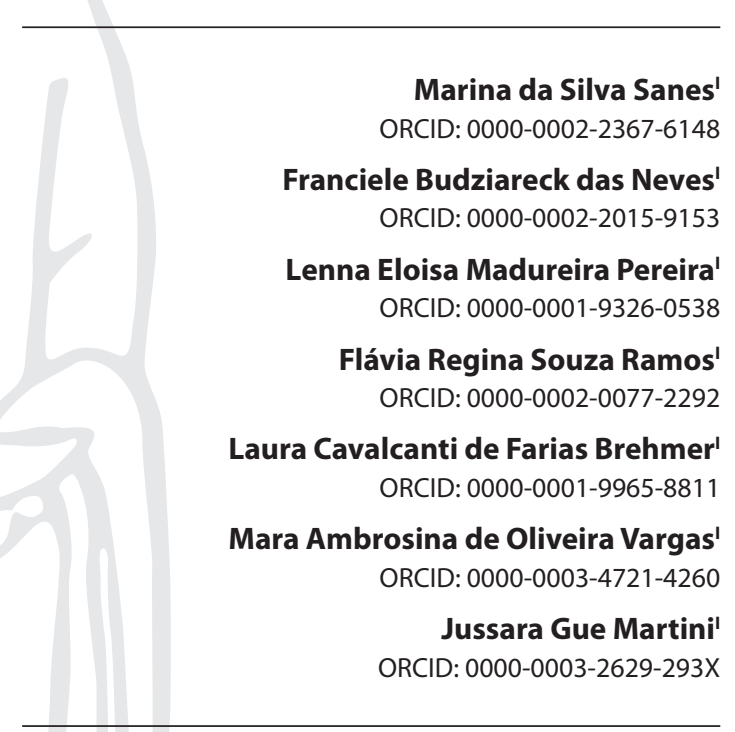

'Universidade Federal de Santa Catarina. Florianópolis, Santa Catarina, Brazil.

How to cite this article: Sanes MS, Neves FB, Pereira LEM, Ramos FRS, Brehmer LCF, Vargas MAO, et al. No to distance education! Production of meaning of discourses of nursing representative entities. Rev Bras Enferm. 2020;73(5):e20190465. doi: http://dx.doi.org/10.1590/0034-7167-2019-0465

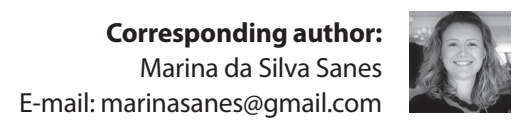

EDITOR IN CHIEF: Antonio José de Almeida Filho ASSOCIATE EDITOR: Marcos Brandão

Submission: 09-08-2019

Approval: 03-23-2020

\begin{abstract}
Objectives: to analyze the processes of production of meanings, based on the positions of Brazilian nursing representative entities, on distance education, considering the implications for nursing as a discipline, profession and work. Methods: this documentary research was carried out in sources from the Federal Nursing Council and Associação Brasileira de Enfermagem, from 2015 to 2018. Data were examined from discourse analysis, using paraphrase and polysemy as analytical devices. Results: they were organized based on the effects of meanings produced and affiliated to two analytical categories: "Forms of mobilization and operating entities" and "Basis and justifications for the positions". Final Considerations: the discourses signal concern about the future training of new professionals. Resistance, participation, visibility, broad and emphatic debate on the topic are shown as strategies for coping and defending a training process less captured by neoliberal logic, and more relational and committed to the quality of health care.
\end{abstract}

Descriptors: Nursing; Education, Nursing; Education, Distance; Education, Higher; Nursing Education Research.

\section{RESUMO}

Objetivos: analisar os processos de produção de sentidos, a partir dos posicionamentos das entidades representativas da enfermagem brasileira, sobre educação a distância, considerando as implicações para a enfermagem enquanto disciplina, profissão e trabalho. Métodos: pesquisa documental, realizada em fontes do Conselho Federal de Enfermagem e da Associação Brasileira de Enfermagem, no período 2015-2018. Dados examinados a partir da análise do discurso, utilizando-se paráfrase e polissemia como dispositivos analíticos. Resultados: foram organizados a partir dos efeitos de sentidos produzidos e filiados a duas categorias analíticas: "Formas de mobilização e atuação das entidades" e "Bases e justificativas dos posicionamentos". Considerações Finais: os discursos sinalizam preocupação com a formação futura de novos profissionais. Resistência, participação, visibilidade, amplo e enfático debate do tema se mostram como estratégias de enfrentamento e defesa de um processo de formação menos capturado pela lógica neoliberal, e mais relacional e comprometido com a qualidade da assistência à saúde.

Descritores: Enfermagem; Educação em Enfermagem; Educação a Distância; Educação Superior; Pesquisa em Educação de Enfermagem.

\section{RESUMEN}

Objetivos: analizar los procesos de producción de significados, desde las posiciones de las entidades representativas de la enfermería brasileña, sobre educación a distancia, considerando las implicaciones para la enfermería como disciplina, profesión y trabajo. Métodos: investigación documental, realizada en fuentes del Consejo Federal de Enfermería y de la Associação Brasileira de Enfermagem, en el período 2015-2018. Datos examinados del análisis del discurso, usando paráfrasis y polisemia como dispositivos analíticos. Resultados: se organizaron en función de los efectos de los significados producidos y afiliados a dos categorías analíticas: "Formas de movilización y desempeño de las entidades"y"Bases y justificaciones para los puestos". Consideraciones Finales: los discursos indican preocupación por la formación futura de nuevos profesionales. La resistencia, la participación, la visibilidad, el debate amplio y enfático sobre el tema se muestran como estrategias para hacer frente y defender un proceso de capacitación menos capturado por la lógica neoliberal, y más relacional y comprometido con la calidad de la prestación de atención en salud.

Descriptores: Enfermería; Educación en Enfermería; Educación a Distancia; Educación Superior; Investigación en Educación de Enfermería. 


\section{INTRODUCTION}

The term Distance Education (DE) has been used since the $19^{\text {th }}$ century in Brazil, with the provision of education by correspondence. Over time, in the $20^{\text {th }}$ century, the modality used new means of communication such as radio and television, culminating in internet use to develop educational actions in contemporary times ${ }^{(1)}$. This modality was regulated in the public and private educational system in 1994, and in Article 80, there is an incentive to the public power for the development and dissemination of DE programs, at all levels and modalities of education and continuing education ${ }^{(2)}$.

Technological development in education in less than 30 years of the Brazilian National Education Guidelines and Bases Law (Lei de Diretrizes e Bases da Educação Nacional, abbreviated LDB) has changed educational spaces, whose possibilities are still expanding. Thus, the incorporation and commercialization of internet in the 90 s brought relative benefits to the different areas of knowledge, rescuing the need for professions to update themselves, or even, have mastery over information technology $\mathrm{y}^{(3)}$.

In the field of nursing, the Ministry of Education is responsible for regulating nursing training, in the role of the Higher Education Office through the Brazilian National Higher Education Assessment System (Sistema Nacional de Avaliação do Ensino Superior, abbreviated SINAES), so that courses must meet regulatory requirements and frameworks proposed for health courses, using $\operatorname{LDB}^{(2)}$ (Law 9394/1996), Decree 9,057/2017(4), the Brazilian National Curricular Guidelines (Diretrizes Curriculares Nacionais, abbreviated DCN $)^{(5)}$, among others.

In turn, the expansion of the offer of higher education in nursing by the private sector has grown since the early 1960s. Higher education then took over greater visibility for certain groups in society as a strategy to obtain better material, social or symbolic positions. The private sector, until then constituted by confessional or community establishments, expanded and presented a business character, that is, institutions that offered low cost courses and with lesser academic requirements ${ }^{(6)}$.

In the current setting of Brazilian nursing education, 324,640 vacancies are offered in 1,048 nursing courses, distributed in public institutions (154) and private institutions $(894)^{(7)}$. Of these, 82,000 vacancies are in the distance modality, with nine courses in activity, highlighting the situation of eight extinct courses (five of them not even started) and the idleness of more than $80 \%$ of the vacancies. Distortion between vacancies and effective enrollments is pointed out in a recent analysis of the regulation of DE in nursing courses and the work of the Federal Council of Nursing (Conselho Federal de Enfermagem, abbreviated COFEN)(1).

Requirements for professionalization and training of Brazilian nursing, the ways in which nursing professionals would be trained have always been at the heart of the development of the profession, involving different social actors. Changes and transformations during this process express the thinking of a society, which, from its political, social, economic and ideological lenses, follows the changes in Brazilian education, whose legal frameworks continue to guide the evolution of training of nurses ${ }^{(8)}$.

Concomitant with the proliferation of media, information technology and scientific discourses around DE, current movements on education and training that have signaled the emergence and need for a discussion on technological resource use for training health professionals, pointing out gaps, doubts and uncertainties. In nursing, for instance, it is pointed out that there is little research in education technology in MERCOSUL, including DE. This shows that there is a setting in frank expansion, which is not yet expressed in the production of knowledge, asking its potentials, challenges and comparisons ${ }^{(9)}$.

Therefore, based on what was presented about higher education in nursing, the regulatory framework of Brazilian education and possibilities of distance learning, one wonders: how the representative nursing entities have been building their positions on the DE learning modality, considering its implications for professional practice?

International studies have shown the importance of DE as a bet to expand access to higher education in nursing ${ }^{(10)}$ and as a possibility for maintaining university institutions, announcing the emergence of a new form of academic community ${ }^{(11)}$. Several experiences around the world have contributed scientifically to academic production on how distance learning can improve results in nursing education, from application in disciplines and modules ${ }^{(12)}$, to curricular organization ${ }^{(13)}$. Concerns remain, such as creation of DE processes that focus on students ${ }^{(14)}$; preparation of professors and students for this educational environment (digital knowledge) ${ }^{(15)}$; reflection on the relevance of pedagogy in the process of building this educational typology, in addition to the technological issue $\mathrm{e}^{(13)}$.

Despite the growth of educational programs in nursing in countries with different economic and cultural characteristics, the challenges posed by the literature demonstrate concern with what is very expensive for nursing: the development of clinical skills for care ${ }^{(16)}$. The scientific literature does not yet have a body of knowledge to answer how distance learning develops skills that involve clinical skills and attitudes for nursing care. DE is a contemporary element of nursing education and cannot be considered non-existent and/or denied, being necessary to dedicate efforts to think about the pedagogy involved in this particular environment. It can then assume a complementary character to traditional classroom teaching, in order to expand the possibilities it adds to the training of future nursing professionals ${ }^{(16)}$.

In this direction, it was decided to analyze the documents selected as a discourse, more specifically, from the perspective of the French discourse analysis (DA) by Michel Pêcheux. This DA is constituted as a confluence discipline, since it is inscribed in a place where three regions of knowledge come together, namely: historical materialism as a theory of social formations, including the role of ideology; linguistics as a theory of syntactic mechanisms and enunciation processes; and finally, discourse theory as a historical determination of semantic processes. What the DA tries to make known is the historical character of the language; and the subject as a result of the relationship between history and ideology. Data do not exist in themselves, since the concomitance of the fact and the event is necessary to have meaning, effects of meanings in the production processes and to understand their constitution and circulation ${ }^{(17)}$.

\section{OBJECTIVES}

To analyze the processes of production of meanings, based on the positions of Brazilian nursing representative entities, on 
$\mathrm{DE}$, considering the implications of this educational modality for nursing as a discipline, profession and work.

\section{METHODS}

\section{Ethical aspects}

The study is structured as a documentary research, and proposes to use documents that are publicly accessible. According to Resolution $510 / 2016$, which deals with research in Human and Social Sciences, it points out that research using public domain information will not be registered and evaluated by REC/CONEP system ${ }^{(18)}$.

\section{Study design}

This is a qualitative research, with a descriptive and exploratory design, of documentary research type, understood here as a research method by establishing a more situated approach to the phenomenon of DE in Brazil. Thus, in this design we have the assessment of the context of production of documents, considering the relationship with authorship, nature and origin ${ }^{(19)}$.

\section{Data collection and organization}

Data were collected in the period from September to October 2018, on the pages of COFEN and ABEn. These entities were considered because of their historical and legal representations in the face of the debate on DE in nursing.

Initially, a free search was carried out on these sites using the terms distance education and nursing/distance learning and nursing. From this initial search, 121 documents were retrieved, including news, charters, recommendations, resolutions, substantiated reports and videos. Considering the first news dated $08 / 25 / 2015$ on the COFEN website and the last dated 08/14/2018, the researchers proposed to do the free search with such a time limit.

Then, these documents were systematized in text tables in Microsoft Word ${ }^{\circ}$, with the breakdown of characteristics such as: entity, year of publication, document title, document structure. The materials received an initial reading treatment, with a consensus pre-selection between three analysts. From this process, the documents that expressed the entities' position on DE in nursing were listed. With the selected material in hand, exhaustive readings were carried out, relating them to the objective of this study.

The following documents comprised the data sources: 1) Consubstantiated Report of the Operation DE Undergraduate Nursing Courses in response to the Federal Public Ministry $\left.{ }^{(20)}, 2\right)$ Report of the Public Hearings Training of Nursing Professionals in Distance Education (21), 3) Maceió Charter for Nursing Education in Brazil - Final Plenary of the $14^{\text {th }}$ SENADEN(22), 4) Curitiba Charter - Final Plenary of the $15^{\text {th }}$ SENADEN $\left.{ }^{(23)}, 5\right)$ Florianópolis Charter - Final Plenary of the $16^{\text {th }}$ SENADEN ${ }^{(24)}$.

\section{Data analysis}

The data were analyzed based on the French DA, having the theoretical-methodological framework based on Pêcheux, which considers the relationship between subject, language and history.
It is anchored in a space for questioning the opacity of language, that is, it makes explicit a questioning about accepting language as something neutral. There is a manifest interest in accessing the (symbolic) discourse to understand the meaning expressed by the subjects and conditions of existence, given a historical moment $^{(25)}$. In Pêcheux, the concept of discursive formation (DF) is resignified in the field of DA, as the relation of utterances with regularities, in relation to language, mobilized in matters and ideological positions in the production of discourse. Every DF refers to a given ideological formation ${ }^{(17)}$.

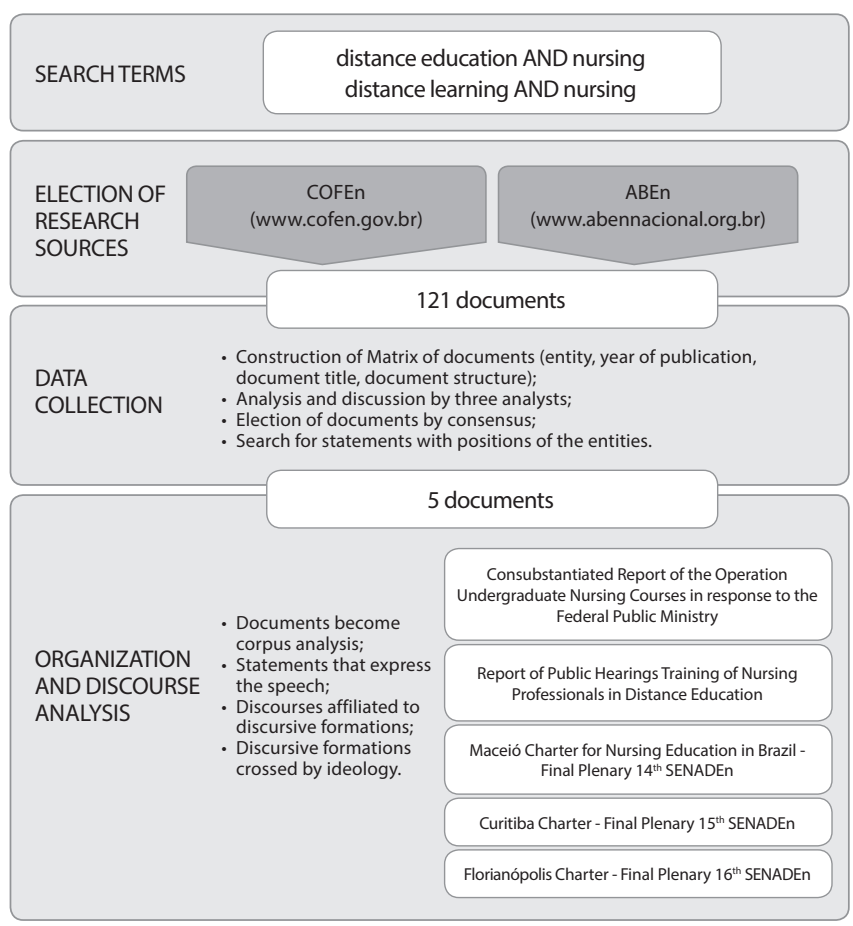

Figure 1 - Systematics of the process of collection and organization of research sources for discourse analysis

For that, paraphrase and polysemy were used as analytical devices ${ }^{(17)}$, assumed as complementary in the constitutive tension of language, considering the paraphrase as the return to what was said in a discourse statement, having the same meaning, and polysemy as the break with the continuity of the discourse, a meaning shift from the memory of saying ${ }^{(26)}$. It is possible to distinguish discourse in: authoritarian, to the extent that polysemy is contained; controversial, in which the polysemy is controlled by means of a dispute among interlocutors, in a tense relationship of dispute for meanings; playful, when polysemy is open, and interlocutors are exposed to the effects of the presence of the referent, not regulating their relationship with meanings. However, it is signaled that the authoritarian factor is due to the injunction to paraphrase and not to a moralistic character in the dialogue. It becomes necessary to subscribe to the repeatable in order to join and promote a formulation that has already been signified, where subjects identify themselves, because without repetition there is no meaning, much less interpretation. On the other hand, if there is paraphrase, it is because there is productivity in language. It is necessary to value that polysemy opens paths 
and space for drifting, for sliding, with its effects of meaning enunciated in processes of (re)signification of discourses. Finally, in this regard, it is observed that a discourse does not take place entirely as authoritarian, playful or controversial, as there is a concomitance of this triad. However, there is a preponderance of one over the other. The authoritarian does not function in its homogeneity, but articulates in its monosemia in the same way as the playful in its polysemy, and the polemic works between polysemy and paraphrase ${ }^{(17)}$.

\section{RESULTS}

The results were organized based on the effects of meanings produced and affiliated to two analytical categories: "Forms of mobilization and operating entities" and "Basis and justifications for the positions".

\section{Forms of mobilizing and operating entities}

The discourses evidenced by entities are produced within the relationships between the members/actors of such entities. It is possible to point out paraphrastic processes, returning to the idea of maintaining the way they produce meaning and how they share these discourses with the rest of society.

COFEN uses a discourse that is contrary to $D E$, even before the theme has a more expressive repercussion. Moreover, the institution presents the way in which, strategically, it will publicize and strengthen the discussion among nursing professionals. This occurs through the realization of two strategies: the holding of hearings among peers and the completion of Operation DE, both activities developed and operationalized in almost all Brazilian states.

Even considering that the regulation of undergraduate courses is an assignment of the Brazilian Ministry of Education (Ministério da Educação, abbreviated MEC), COFEN developed the Operation DE over the course of nine months, in 2015, through a diagnostic visit to On-Campus Support Poles of Undergraduate Courses Active DEs, by Supervisory Departments of the Regional Councils.

With regard to hearings, COFEN means them as instruments to fight against DE. In this meaning, even assuming a consultative character, they allow professionals to debate the theme and become aware of the situation:

The public hearing is an awareness tool that [...] works as a vehicle for legitimate participation in issues of public interest, which leads to a political or legal decision with legitimacy and transparency [...] is through it, and under conditions of equality, which we listen to the most varied opinions on the discussed matter, in direct contact with the interested parties. (COFEN, Report Hearings, 2016 p. 7) (free translation)

The condition for COFEN intervention in the reality of DE is built by the fragmented performance of the autarchy, which, due to its own regulating profession, is present in all Brazilian states, creating conditions to reverberate discourses about DE and to access professionals of nursing. The methodological option adopted by COFEN, public audience, is an instrument used from an intentionality: collective and collectivizing process, which occurs in the contact, relationship and debate between professionals.
ABEn takes a position on DE that is organized, also in the relationship among its members, that is, it uses its historical legacy to hold events of national interest to debate themes that emerge as relevant to the professional category. It is observed that in the last three charters, approved in the final plenary sessions of Brazilian National Seminars of Guidelines for Education in Nursing (Seminários Nacional de Diretrizes para a Educação em Enfermagem, abbreviated SENADEn), DE was mentioned. Added to this, the notion that ABEn, in the function of its national boards and state sections, was also present in several discussion spaces promoted by COFEN.

From the perspective of DA, the forms of mobilization of both representative entities of nursing produce meaningful effects on the collective of the category, either through the discourse of regulations that dictate social and legal positions (COFEN) or through the discourse of positioning and development of the profession (ABEN).

Among the discourses identified as outliers in the positions, those that produce the new or intend to change, it is understood that COFEN inaugurates a derivative discourse when performing and taking over the activity of visiting the hubs, which is not its responsibility as executor, is accepted among its members:

The proposal for a visit by the Supervisory Departments of the Regional Nursing Councils to On-Campus Support Poles of the Undergraduate Nursing Courses in distance education mode was defined by the COFEN Technical Chambers and unanimously approved in the Assembly of Presidents of the Regional Nursing Councils. (Operation DE, 2015) (free translation)

The process comes from Inspection Departments, experienced in monitoring the legal exercise of the profession, and that it resignifies the legitimacy for its performance by being approved in the highest instance of deliberation among the presidents of the Regional Nursing Councils. Polysemy, in the constitution of this position, demonstrates once again the intentionality of autarchy not only to understand what was happening in these centers, but to appropriate something that was underway: the construction of a position on DE by the entity. Here lies the discursive fold presented by COFEN's discourses: something new is to come, and to act in a new way, displacing meanings and producing others, as a way of not being captured.

\section{Bases and justifications for the positions}

The bases and arguments of entities are based on conceptions about teaching in the distance learning modality, justifications for the positions, and proposals to face the mobilized issues.

COFEN conveys the notion of DE as "educational modality, in which didactic-pedagogical mediation occurs with Information and Communication Technologies (ICT), with students and professors carrying out educational activities in different places or times", which follows what is expressed in the Decree 9,057/2017(4), which regulates Article 80 of Law 9,394, of December 20, 1996, which establishes the guidelines and bases of national education, emphatically linked to the notion that DE:

Is constituted as a privileged way to expand access to Higher Education without increasing state expenditures in a considerable 
way, it implies in raising the country's statistics, strengthening the educational market and, also, spreading to the population a strong consensus around the idea of social ascension via higher education, without touching the structural bases of inequality in the country. (COFEN, Report Hearings, 2016) (free translation)

ABEn also refers to the link of DE to market interests and the need for a critical understanding of the political context of its emergence:

A teaching modality that reinforces the power of capital and private initiative in education, making the State not responsible for competent and safe training for the provision of nursing care based on the real health needs of the population. The refusal of this way of teaching must be maintained in a constant and uncompromising manner. (ABEn, $15^{\text {th }}$ SENADEn, Curitiba, 2016) (free translation)

By the paraphrase device, the maintenance of the COFEN's and ABEn's discourses is made explicit, linking them to a DF that DE is a space for reproducing the logic of capital applied in education. Through one of these discourses, precariousness, lack of conditions and dissociation of the didactic-pedagogical dimension of the activities of the poles emerged, operationalized in the form of outsourcing, as expressed in the statements below:

Courses are legally responsible for the pedagogical and financial didactic dimension and most outsource the Personnel Support Poles. (COFEN, Report Hearings, 2016) (free translation)

These Hubs did not have the minimum physical and technological infrastructure, such as anatomy, biochemistry, physiology, microbiology, immunology, parasitology laboratories, among others [...] nor were specific nursing laboratories found in most of the centers, essential to the training of nurses. (COFEN, Operation $D E$, 2015) (free translation)

In the criticism of $\mathrm{DE}$, a discourse about the damage in the didactic-pedagogical relationship is reinforced, especially in the exercise of the teaching function:

It decentralizes the figure of the professor and creates a new subject: the tutor, who will streamline the face-to-face moment, that is, he receives the "educational package" from the matrix, and applies it to the students. We have no control over the training of tutors or what they produce academically in the field of Nursing, nor how they mediate between the virtual "educational package" received at the distance education centers and the pedagogical relationship with real students. (COFEN, Report Hearings, 2016) (free translation)

Another possible unveiling links the discourses against distance learning to the relationship between quality of training and quality and security of health care. In other words, a FD that is anchored in the synchrony of the discourses, using the paraphrase: DE is detrimental to training, too, because it represents insecurity for care.

Students generally take the Course in distance learning centers, located in small and medium-sized municipalities and these do not usually appoint new jobs. [...] any insecurity in assistance may represent irreparable damage, for a society already so lacking in quality health. (COFEN, Report Hearings, 2016) (free translation)

COFEN is extremely opposed to distance education in nursing, as it has the conviction that the advent of errors and damages caused by malpractice, negligence and imprudence in assisting the population, will be even greater than this already occurs with training in classroom courses. (COFEN, Report Hearings, 2016) (free translation)

In the same vein as the paraphrases that embody DF, the positions taken in relation to social protection, safety and legality are added, highlighting central elements of social nursing practice, an aspect that is always reinvigorated when the question is the identity construction of the profession and in society, repeatable in different ways:

Nursing comprises its own component of scientific and technical knowledge and is built by a set of social, ethical - legal and political practices that are processed through teaching, research and assistance. It takes place in the provision of services to the person, the family and the community, in compliance with the principles of the Brazilian Unified Health System (Sistema Único de Saúde, abbreviated SUS), in the various stages of life, often fragile and at risk of death. (COFEN, 2016, p. 5) (free translation)

It was recommended to join forces and gather mobilization strategies for firm action with the deliberative bodies with a view to the approval of normatization devices prohibiting this type of teaching, which is extremely harmful to the quality of professionals who train and the assistance provided by them. (ABEn, Curitiba Charter, 2016, p. 4) (free translation) (free translation)

COFEN/Regional Nursing Councils suspend the registration of graduates of these HEls until the position of the Federal Public Ministry, as well as requiring that the MPF, following the position of this Council, act with the Ministry of Education seeking to cancel the accreditation of these HEls, for not comply with current legislation and do not meet the minimum requirements for the training of nurses. (COFEN, Operation DE, 2015) (free translation)

In a purposeful way, suggestions for actions and agreements are made around the convergence of interests and reinforcement of the mobilization of entities. Some refer to actions or measures to be created: permanent discussion group on innovative pedagogical tools and models in classroom teaching with distance strategies (ABEn); national network of open educational resources in nursing (ABEn); broadening of the debate on ICT (ABEn). Also, the maintenance of actions is recommended, such as interprofessional and interinstitutional articulation, investing in efforts contrary to $D E$ in health, at all levels of education (ABEn) and permanent vigilance over the political direction of education and health in the country (ABEn). As guiding actions, SUS democratic and participatory principles, social, political, economic rights and the guarantee of constitutional rights are expressed, fundamentals that have always been very expensive for Brazilian nursing and that remain as values to be pursued in the exercise nursing professional.

\section{DISCUSSION}

The representative entities of nursing, ABEn and COFEN, stood out as the most expressive fronts of DF on DE in nursing. $A$ 
leading movement triggered, as of 2015, a process of publicizing national discussion placing DE on the agenda. By privileging such discursive actors, the performance of so many other actors is not denied, as well as their ability to articulate the collective actor ("professionals") when speaking for and for him. Furthermore, it is necessary to return to the historical-political context of these actors and their mechanisms of action, also with congruencies and specificities. Congruences in the meaning that they are entities/ organizations that provide bases or reinforce at least one of the conditions of a profession - that of having entities that represent it in society and that postulate/regulate professional practice and ethics ${ }^{(27)}$. Specificities in the meaning of its different objectives, organization and internal participation, which has repercussions on the dynamic mechanisms or strategies, used by one and the other, also in observable transformations.

The concern with nursing education in Brazil dates back to 1929, in adherence to ABEn's first statute, when it assumed a relevant role in the theme of education and the future of the profession. It is important to give visibility to the historical construction of SENADEn, which from 1994 onwards initiates a process of discussion on training and the professional profile, in the logic of giving priority to the quality of assistance and professional training. After 16 editions of SENADEn carried out, the entity continues to debate and position itself in society, understanding that it is necessary to remain vigilant in relation to the announcement of training policies that may compromise the interests of the profession ${ }^{(28)}$.

COFEN's role in proposing Operation DE and public hearings expands the entity's scope of struggle, creating a permanent space for disseminating information about DE and its activities. The capacity for participation occurs in praxis, combining practice, technique, creation and theory, that is, that it is only possible to learn about participation in the collective experience ${ }^{(29)}$. In this way, the movement triggered by COFEN is connected to the ideas of participation in the logic of the development of critical awareness and empowerment.

The Brazilian National Health Board (Conselho Nacional de Saúde, abbreviated (NS), as an instance of social control and recognized by the plurality of representation of users, workers, managers and service providers in SUS, follows discourses against DE, intending to build a greater debate in society. In its composition there are representations of workers and, in the period analyzed, representatives of nursing entities were active. In this perspective, CNS is an actor to be recognized, although not highlighted as a source of analysis, of which the recommendation document addressed to the Minister of State for Education stands out, reaffirming and legitimizing previous positions of entities representing health professions. , as well as the constitutional competence of SUS in ordering human resources in health ${ }^{(30)}$.

In another meaning, some discourses inaugurate new ways of expressing the mobilization of entities. It is perceived that the role of entities such as COFEN and ABEn in the regulation of higher education in Brazil occurs outside a character of legal responsibility, but through strategies to make themselves heard and influence the flow of decisions. Thus, COFEN, when proposing visits to all DE centers registered with $M E C$, extrapolates their prerogatives and is based on the defense functions of a training that considers the minimum criteria for professionalization, including in this scope also the monitoring higher education institutions. In this way, it considers the effectiveness of its role in society and within the category ${ }^{(31)}$, which implies direct action in the interests of the class and in what directly interferes in the professional exercise ${ }^{(32)}$.

By taking advantage of the prerogative of professional entities, which justify their performance precisely because they defend the attribute of nursing as a profession, COFEN and ABEn use a double role, combining the defense of the profession and society, against possible damage from impaired training/precarious to provide the quality of professional practice, that is, to achieve the work's purpose, the care provided and socially necessary.

As already traditionally indicated in sociological analyzes and already applied to the field of nursing ${ }^{(27)}$, attributes of a profession refer to its specialized and regulated qualification; its representation and internal regulation (entities and ethics); its social recognition and legal legitimacy; and its mastery of a field of knowledge. There are variations in the description of these conditions, which are intrinsically linked to competence and autonomy. What is assumed here is that the discourses analyzed evoke such conditions and are justified based on them, but do not explicitly or necessarily restrict themselves to sociological analyzes. They use socially-accepted assumptions, such as the connection between nursing and care, what in fact characterizes their work process, as well as education and administration/management at different levels and spaces. Nursing work is developed collectively and in collaboration with other professionals and workers. It is based on knowledge appropriate to coping with problems in the health field and its professional nucleus ${ }^{(27)}$, that is, to act on its object of work (the human being) develops its epistemological object $(\text { care })^{(33)}$. The in-depth understanding of its object, health needs and care itself is the basis for professionalization, which makes impractical a teaching modality that reduces direct contact with reality, caring in vivo and in multiple settings. The competence for care comes from the discipline of nursing, when developing pertinent knowledge about the object and the work instruments, legitimately formulated and transmitted by science and academia and, also, from the socializing and identity-building practice.

Work not only needs to have quality, but also to promote the employee's subjective learning and engagement, with a view to the future and lifelong learning ${ }^{(34)}$. Educating future professionals is also the prerogative of a profession. Now, when embracing arguments so mutually interwoven, as are profession, discipline and work, discourses share the same meaning (paraphrases) of criticisms in relation to the distance learning modality in nursing courses. Such criticisms are required to defend the competence, autonomy and responsibility of a profession legitimized in science, law and social practice.

In turn, signifying DE as capable of making the individual rise socially, raising education statistics in the country without changing social inequalities ${ }^{(30)}$ demanded to denounce the market interests that involve DE and education as a commodity; DE in nursing/health as a dissociation of the didactic-pedagogical dimension and the teaching function, as harmful to training and safety of care. Mobilizing in nursing is expressed by ways of acting congruent among the actors, in a defense of nursing revealed in the highlighted paraphrases. A discourse that wants 
to be dominant, strengthened, that remains in the struggle of a category, for the entities analyzed here, is a discourse that is said to be contrary to DE since its debate, since its mobilization, with an expressive number of spaces for discussion. (public hearings) and legitimacy (National Seminars). Higher education valorization as a form of social ascension is related to the achievement of social recognition and link to a professional identity. In this way, the profession is characterized as a project of prestige and power, aiming at social recognition and the privileges of professional domains ${ }^{(35)}$.

Notwithstanding, $\mathrm{CNS}^{(30)}$ reminds us that distance learning is only a device applied in face-to-face undergraduate courses, within the supply limit not exceeding $20 \%$ (twenty percent) of the total course load. This same limit, which was anchored in Ordinance 1,428 , of $12 / 29 / 2018$, was increased to $40 \%$, on $12 / 06 / 2019$, by Ordinance $2,117^{(36)}$, in addition to reducing the applicability of the limit for courses with concept 3 in several indicators related to DE, hurting LDB (Law 9.394, of $1996^{(2)}$ and pulverizing the distinction between the subsidiary or complementary use of DE and its offer as a teaching modality. It is understood that mediation by remote technologies is a resource to facilitate and expand access to part of a component or discipline, but that it should not be used as a total resource for conducting training. Here is one of the relevant points: the partial and assertive use or expanded and full use without considering the specificities of a training that teaches/learns how to care for people with complex needs and in different settings?

Among the initiatives to block DE, there is Bill 2891/2015(37), proposed by Deputy Orlando Silva, from the party PC do B-SP, which suggests amending Law 7,498/1986, which regulates the professional practice of nursing, to include that nursing training must be mandatory on-site. The proposal finds support in the DE Reports analysis produced by COFEN. Concerning health, two projects of the same content are also pending in the Chamber of Deputies: Bill 1171/2019 ${ }^{(38)}$, by Deputy Dr. Jaziel (PR-CE) and Bill $5414 / 2016^{(39)}$, by Rodrigo Pacheco (PMDB-MG). They suggest an amendment to Article 80 of Law 9,394/1996, exposing the need to safeguard health courses from encouraging public power to DE programs.

As an ideology, the discourses conveyed by the analyzed institutions observe the questioning of the liberal logic of higher education, and the limits that this logic imposes on nursing education in Brazil. Current higher education is based on the corporate organizational model, with income as an end, minimum workload as a means and market laws as a condition, which does not always effectively prepare critical and ethical professionals. The product of this model, guaranteed by state regulation, are "professionals" who are children of the market, often distant from social awareness, without class identity, purely functional(40).

As it is a huge working class in Brazil, with stratifications and hierarchies, nursing attracts market interests and facilitates the tendency of proliferation of institutions that, for profit, offer cheap courses, with average concepts or at the minimum limit to be authorized and recognized by MEC.

To compose the unspoken discourses, it is necessary to refer to the history of higher education and its policies. Reinforcing inequality in Brazil, the neo-liberalist-conservative model has the support of political, economic and intellectual elites, who validate a highly selective meritocracy system ${ }^{(41)}$. The wide authorization of distance learning courses by MEC shows a pro-democratization discourse of access to higher education, via private institutions or even subsidized by the legacy of "contribution to development, concept, methods and techniques that promote flexible open distance education"(42). However, the idea of free access has an illusory meaning, if it does not alter structural issues of social inequality.

In addition to the list of discourses critical to $D E$, there is an alert regarding a potential deterioration of the didactic-pedagogical relationship, based on the role of tutor as a substitute for the professor. The shift in the historically constructed meaning of the professor is accentuated. Practice is built in the relationship with the student, mediated by the world ${ }^{(43)}$ and in the idea that dialogue sustains the pedagogical relationship, in the assertion that the teaching-learning process is not knowledge transfer and that, undoubtedly, professors are people prepared for a pedagogical, conscious, creative and reflective act ${ }^{(44)}$.

In fact, the assertion that the tutor does not have necessary training to prepare nursing professionals is questioned. Professor education is another central element in this educational perspective, in which professors leave their master's profession to be "pinwheel" professors, placed in a place of reproduction of the most recent political and technological wills, where ideology even crosses the teaching identity itself: who am I but someone modernized and digitally included (read subject to the avalanche of capital on teaching practice) ${ }^{(45)}$ ? Thus, distance learning announces what the new professor should be like, his/her profile and new role in the face of the erasing of the teaching, socializing and humanizing function of the educational act.

In the same critical line, damage to the didactic-pedagogical relationship is aggravated by the performance of tutors who implant/deliver ready-made educational packages, a dissociation between thinking about the educational act and developing the process. Criticism is not directed at the person of the tutor directly, but one who does not participate in the entire educational process, who does not assume the teaching function in its breadth, who is deprived of the right to do so. This is yet another demonstration of the weakness in understanding teaching as a professional activity and, consequently, of little interest in the pedagogical act and in everything it carries. Distance learning can limit the space for creation, encounter and change, that is, for the political dimension of teaching. This professor-tutor exchange, intentionally produced within the tools of power, dialogues more with an idea of silencing the teaching role by the totalizing ways of educating proposed by capital, than with an idea of expanding access to higher education presented with a purpose of development. Teaching, which intends to be purposeful, technical-political mediator of the educational act, whose ontological assumption is also political, is being blurred and forgotten with a purpose ${ }^{(46)}$.

Among the justifications of the entities for taking a stand against the distance learning modality, the importance of academic quality is assumed for a care free of damages to society and for the articulation of teaching, research and assistance within SUS and care practices, in contact with the user of health services. 
Nursing is part of the field of health work, but it is distinguished from the work of other professionals by the uniqueness of professional care ${ }^{(47)}$.

In addition to this thinking, ABEn brings a new element to be considered in professional training, namely, the need to agree on the use of technologies, in order to discuss, qualify and know ICTs that can be used to facilitate and aggregate knowledge. This need for discussion emerges from the desire for the availability of technologies that complement educational practices, which are already widely used to complement nursing education. Qualifying the teaching-learning process with tele-education, developing strategies to improve the care provided, offering permanent training actions are uses already documented in the pedagogical practice in nursing, and it is not possible, at this moment, to map any pedagogical process developed at a distance in its entirety $^{(48)}$. In this way, it is possible to read that even in scientific communication between peers, in specific nursing journals, it is not possible to find essays, original articles and reports of experiences of the modality totally at a distance, except in cases used in a complementary way.

ICTs are devices that provide products, that is, goods and services, alleviate efforts and resolve difficulties, can be linked to organizational, educational and support systems, assistance programs and protocols, from which care and health care are provided the population. Debates on ICT permeate several settings, among companies, development agencies and several social organizations, including the health sector. It is common for organizations, institutions and companies to place continuing learning and production of new knowledge and technologies as a strategic center for their survival and growth, characterizing contemporary society as the historical period of knowledge and technology ${ }^{(49)}$.

It is important to discuss that ICT, responsible for significant changes in social relations, are the result of social work and that, in the capitalist mode of production, they are configured as a commodity subject to the law of the market. Technology-mediated education will have consistency if it is linked to a planned, consistent pedagogical political project that guarantees pedagogical actions consistent with the teaching modality and with the target audience ${ }^{(50)}$. Therefore, ICT can collaborate in teaching, promoting learning strategies, encouraging autonomy in a collective and knowledge sharing perspective. Distance learning is not simply a product of the technologies used in education, but it must be a means of integrating education to support and complement training.

\section{Study limitations}

As factors limiting this research, aspects related to the multiplicity of information and entities that express their positions appeared, requiring the authors to work rigorously in the face of the documents that best expressed the positions. Other studies may take different perspectives in order to compose and expand this debate in the Brazilian setting, such as the inclusion of documents produced by the Ministries of Health and Education. Thus, this is a possible analysis lens. As with theoretical-methodological elections, which do not constitute limitations as such, it is pointed out that other perspectives of DA from different perspectives could be interesting.

\section{Contributions to nursing}

By focusing on a topic of debate in the current professional environment, professional training and impacts on nursing are articulated, recognizing the connection between disciplineprofession-work. It is understood that considering the phenomena analyzed in this perspective allows nursing to continue taking responsibility for the process of professional socialization, consolidation and evolution of its area of knowledge and new perspectives on its work and epistemological objects.

\section{FINAL CONSIDERATIONS}

DE is a reality in Brazil and in the training of nursing professionals, which has placed the theme in several spaces for dialogue, requiring the involvement of different discursive agents and deepening its multiple directions and implications. The study made it possible to access the construction of positions by COFEN and ABEn, their mobilizations on distance learning, calling for affiliation to the discourse "No to distance learning". Furthermore, it is a discourse that gains approval in the sphere of social control, being endorsed by the CNS and by the various representations that comprise it.

Despite the DA presupposing polyphony and heterogeneity, the elements of repetition and redundancy were the most evident. Less than a polysemy, it proved to be synchrony or a relatively aggregated discourse, perhaps due to the very political conditions of existence, which today make it difficult to express favorable positions for DE in nursing, previously refuted in terms of acceptance in the professional field. Despite producing discourses in different spheres, coherence consolidates a position of Brazilian nursing, of mutual enhancement of the actors' discourses, to produce meaning within the institutions and among its members.

DA contributed to understand the conditions of production of discourses against distance learning, by revealing that it is not the distance learning mode itself or ICT use that causes harm to nursing education, however, the power forces that support these tools, operated under the aegis of capitalist market logic. It was through DA that it was identified that DE is anchored in the neoliberal and technological paradigms and has a strong impact on the field of education. However, when casting a dialectical look, such a stance finds tension in the discourses against the DE of Brazilian nursing entities, for which resistance, participation, visibility and broad debate on the topic seem to be strategies for coping and defending a less captured training process by neoliberal and more humanized and relational logic.

In view of the market logic in the area of education, discourses signal concern about the future of training new professionals, lacking material, human and pedagogical resources, since DE does not guarantee comprehensive practices with human beings. The way in which technology is transmitted to the user is also a focus of concern, as cheap, medium-term courses are announced, with reduced educational structure and without preparation for the reality of health care. 
DE magnitude in health courses, especially in nursing, shows that an analysis in relation to the legal, normative and operational framework of DE is urgent. The proposal for the effective insertion of professional Councils in the elaboration and monitoring of curricular guidelines for higher education, surpassing the traditional view of tax entities, constitutes a welcome and prominent proposal in the considered considerations. The capacity of institutions to influence in a consultative and participatory way in the decisions to offer distance learning courses in the health field must remain a purposeful target on the part of entities.

\section{FUNDING}

This study was funded by Coordination for the Improvement of Higher Education Personnel - Brazil (Coordenação de Aperfeiçoamento de Pessoal de Nível Superior, abbreviated CAPES).

\section{REFERENCES}

1. Humerez DC, Silva MCN, Ohl RIB, Jankevicius JV, Dias OV, Borges RF. Normativas regulatórias dos cursos de enfermagem a distância: ações e reações do Conselho Federal de Enfermagem. Enferm Foco [Internet]. 2019[cited 2020 Jan 2];10(2):142-8. Available from: http://revista. cofen.gov.br/index.php/enfermagem/article/view/2338/535

2. Presidência da República (BR). Subchefia para Assuntos Jurídicos. Lei no 9394 de 20 de dezembro de 1996. Dispõe sobre as diretrizes e bases da educação nacional [Internet]. Brasília, DF; 1996[cited 2018 Oct 25]. Available from: http://www.planalto.gov.br/ccivil_03/leis/l9394.htm

3. Maliska ICA. A organização da enfermagem e da saúde no contexto da Idade Contemporânea: a revolução tecnológica (1990-2008). In: Padilha MIC, Borenstein MS, Santos I (Ed.). Enfermagem: história de uma profissão. 2a ed. São Caetano do Sul, SP: Difusão Editora; 2015. p. 335-378.

4. Ministério da Educação (BR). Decreto n० 9.057, de 25 de maio de 2017. Regulamenta o art. 80 da Lei no 9.394, de 20 de dezembro de 1996, que estabelece as diretrizes e bases da educação nacional. [cited 2019 Oct 10] Available from: http://www.planalto.gov.br/ccivil_03/_ Ato2015-2018/2017/Decreto/D9057.htm

5. Ministério da Educação (BR). Resolução № 3, de 07 de novembro de 2001. Institui Diretrizes Curriculares Nacionais do Curso de Graduação em Enfermagem [Internet]. Brasília: Conselho Nacional de Educação. Câmara de Educação Superior. 2001 [cited 2018 Nov 10]. Available from: http://portal.mec.gov.br/cne/arquivos/pdf/CES03.pdf

6. Leonello VM, Miranda Neto MV, Oliveira MAC. Nursing higher education in Brazil: a historical view. Rev Esc Enferm USP. 2011;45(spe2):17741779. doi: 10.1590/S0080-62342011000800024

7. Ministério da Educação (BR). Cadastro Nacional de Cursos e Instituições de Educação Superior. Cadastro e-MEC [Internet]. [cited 2020 Jan 8] Available from: http://emec.mec.gov.br/

8. Barreira IA, Baptista SS, Sauthier J, Santos TCF, Peres MA, Oliveira AB, Almeida Filho AJ. Primeira República: a implantação da enfermagem laica e seus desdobramentos (1889-1930). In: Padilha MIC, Borenstein MS, Santos I (Ed.). Enfermagem: história de uma profissão.. 2a ed. São Caetano do Sul, SP: Difusão Editora; 2015. p. 219-252.

9. Winters JRF, Prado ML, Lazzari DD, Jardim VLT. Nursing higher education in MERCOSUR: a bibliometric study. Rev Bras Enferm. 2018;71(Suppl 4):1732-9. doi: 10.1590/0034-7167-2017-0405

10. Ghezeljeh TN, Aliha JM, Haghani H, Javadi N. Effect of education using the virtual social network on the knowledge and attitude of emergency nurses of disaster preparedness: a quasi-experiment study. Nurse Educ Today. 2019;73:88-93. doi: 10.1016/j.nedt.2018.12.001

11. Kozlowski-Gibson M. Online nursing education: Reform from within our humanity. Nurse Educ Today. 2018;68:75-77. doi: 10.1016/j. nedt.2018.05.031

12. Mazanec P, Ferrell B, Malloy P, Virani R. Educating Associate Degree Nursing Students in Primary Palliative Care Using Online-E-Learning. Teach Learn Nurs. 2019;14:58-64. doi: 10.1016/j.teln.2018.10.002

13. Lewis PA, Tutticci NF, Douglas C, Gray G, Osborne Y, Evans K, Nielson CM. Flexible learning: Evaluation of an international distance education programme designed to build the learning and teaching capacity of nurse academics in a developing country. Nurse Educ Pract. 2016;16: 59e65. doi: 10.1016/j.nepr.2016.10.001

14. Khan E, Tarling M, Calder I. Reusable learning objects for nurse education: development, evaluation, challenges and recommendations. British J Nurs. 2019;28(17):1136-46. doi: 10.12968/bjon.2019.28.17.1136

15. Griffiths B. A Faculty's Approach to Distance Learning Standardization. Teach Learn Nurs. 2016;11:157-62. doi: 10.1016/j.teln.2016.04.004

16. McDonald EW, Boulton JL, Davis JL. E-learning and nursing assessment skills and knowledge: an integrative review. Nurse Educ Today. 2018;66:166-74. doi: 10.1016/j.nedt.2018.03.011

17. Brasil LL. Michel Pêcheux e a teoria da análise de discurso: desdobramentos importantes para a compreensão de uma tipologia discursiva. Linguagem: Estud Pesqui. 2011;15(1):171-82. doi: 10.5216/lep.v15i1.25149

18. Brasil. Ministério da Saúde. Resolução № 510, de 07 de abril de 2016 [Internet]. Brasília: Conselho Nacional de Saúde, 2016. [cited 2018 Nov 8] Available from: http://bvsms.saude.gov.br/bvs/saudelegis/cns/2016/res0510_07_04_2016.html

19. Andrade SR, Schmitt MD, Storck BC, Piccoli T, Ruoff AB. Documentary analysis in nursing theses: data collection techniques and research methods. Cogitare Enferm. 2018;23(1):e53598. doi: 10.5380/ce.v23i1.53598. 
20. Conselho Federal de Enfermagem. Relatório Consubstanciado da Operação EAD Cursos de Graduação em Enfermagem em resposta ao Ministério Público Federal [Internet]. Brasília; 2015[cited 2018 Sep 10] Available from: http://www.cofen.gov.br/relatorio-consubstanciadoda-operacao-ead-cursos-de-graduacao-em-enfermagem-em-resposta-ao-mpf_35188.html

21. Conselho Federal de Enfermagem. Relatório das Audiências Públicas Formação de Profissionais de Enfermagem na Modalidade à Distância [Internet]. Brasília. 2016[cited 2018 Sep 10] Available from: http://www.cofen.gov.br/wp-content/uploads/2017/03/RELAT\%C3\%93RIOAUDI\%C3\%8ANCIAS-P\%C3\%9ABLICAS-\%E2\%80\%93-FORMA\%C3\%87\%C3\%830-DE-PROFISSIONAIS-DE-ENFERMAGEM-NA-MODALIDADEEAD-final-1.pdf

22. Associação Brasileira de Enfermagem. Carta de Maceió para a Educação em Enfermagem no Brasil [Internet]. $14^{\circ}$ Seminário Nacional de Diretrizes para a Educação em Enfermagem. 2014[cited 2018 Sep 10] Available from: http://www.abennacional.org.br/site/wp-content/ uploads/2019/02/cartamaceio.pdf

23. Associação Brasileira de Enfermagem. Carta de Curitiba [Internet]. $15^{\circ}$ Seminário Nacional de Diretrizes para a Educação em Enfermagem. 2016. [cited 2018 Sep 10] Available from: http://www.abennacional.org.br/site/wp-content/uploads/2019/02/15SENADEN2016.pdf

24. Associação Brasileira de Enfermagem. Carta de Florianópolis [Internet]. 14 Seminário Nacional de Diretrizes para a Educação em Enfermagem;2018 [cited 2018 Sep 10]. Available from: http://www.abeneventos.com.br/16senaden/anais/edicao-carta.htm

25. Barros THB. Por uma metodologia do discurso: noções e métodos para uma análise discursiva. In: UNESP, E. (Ed.). Uma trajetória da Arquivística a partir da análise do discurso: inflexões histórico-conceituais [Internet]. 2015 [cited 2018 Sep 10]. São Paulo: [s.n.]. p. $73-95$. Available from: https://repositorio.unesp.br/handle/11449/138613.

26. Orlandi EP. Paráfrase e polissemia: a fluidez nos limites do simbólico. RUA. 1998;4(1):9-20, 1998. doi: 10.20396/rua.v4i1.8640626.

27. Pires DEP. Transformações necessárias para o avanço da Enfermagem como ciência do cuidar. Rev Bras Enf. 2013;66(spe):39-44. doi: 10.1590/S0034-71672013000700005

28. Mancia JR, Padilha MIC, Ramos FRS. A organização da enfermagem brasileira. Parte 1: ABEN. In: Padilha MIC, Borenstein MS, Santos I (Ed.). Enfermagem: história de uma profissão. 2a ed. São Caetano do Sul, SP: Difusão Editora; 2015. p. 411-448.

29. Budó MLD, Beck CLC, Dal Sasso GTM, Gonzales RMB. Collective responsability and nurses' participation in professional institutions. Rev Bras Enferm. 2001;53(4):237-247. doi: 10.1590/S0034-71672001000200009

30. Ministério da Saúde (BR). Recomendação 69, de 13 de dezembro de 2017 [Internet]. Brasília: Conselho Nacional de Saúde. [cited 2018 Sep 22] Available from: http://conselho.saude.gov.br/recomendacoes/2017/Reco069.pdf

31. Silva MCN. O Conselho Federal de Enfermagem no desenvolvimento de Políticas Públicas do Sistema Único de Saúde: Perspectivas e Desafios. Enferm Foco. 2016;7(esp):77-80. doi: 10.21675/2357-707X.2016.v7.nESP.698

32. Pires DEP; Lorenzetti J; Albuquerque GL. A organização da enfermagem brasileira. Parte 2: O "Movimento Participação" na Associação Brasileira de Enfermagem (ABEn): história e desafios na representação profissional. In: Padilha MIC, Borenstein MS, Santos I (Ed.). Enfermagem: história de uma profissão. 2a ed. São Caetano do Sul, SP: Difusão Editora; 2015. p. 449-477.

33. Leopardi MT, Gelbeck FL, Ramos FRS. Cuidado: objeto de trabalho ou objeto epistemológico da enfermagem? Texto Contexto Enferm. 2001 [cited May 18];10(1):32-49. Available from: https://pesquisa.bvsalud.org/portal/resource/pt/bde-437

34. Dubar C. A construção de si pela atividade de trabalho: a socialização profissional. Cadernos de Pesquisa. 2012;42(146):351-367. doi: 10.1590/S0100-15742012000200003

35. Pimenta AL, Souza ML. The professional identity of nursing in the papers published by Reben. Texto Contexto Enferm. 2017;26(1):1-9. doi: 10.1590/0104-07072016004370015

36. Ministério da Educação (BR). Portaria N. ${ }^{\circ}$ 2117, de 6 de dezembro de 2019. Dispõe sobre a oferta de carga horária na modalidade de Ensino a Distância - EaD em cursos de graduação presenciais ofertados por Instituições de Educação Superior - IES pertencentes ao Sistema Federal de Ensino. Available from: http://www.in.gov.br/en/web/dou/-/portaria-n-2.117-de-6-de-dezembro-de-2019-232670913

37. Câmara dos Deputados (BR). Projeto de Lei 2891/2015. Altera a Lei n 7.498, de 25 de junho de 1986, que regulamenta o exercício da enfermagem, para nela incluir a obrigatoriedade de formação exclusivamente em cursos presenciais para os profissionais da área [Internet]. 2015 [cited 2020 Jan 6]. Available from: https://www.camara.leg.br/proposicoesWeb/fichadetramitacao?idProposicao=1712329

38. Câmara dos Deputados (BR). Projeto de Lei 1171/2019. Dá nova redação ao artigo 80 da Lei n 9.394, de 1996 - Lei de Diretrizes e Bases da Educação [Internet]. 2019[cited 2020 Jan 6]. Available from: https://www.camara.leg.br/proposicoesWeb/fichadetramitacao?idProposic ao $=2193204$

39. Câmara dos Deputados (BR). Projeto de Lei 5414/2016. Altera o artigo 80 da Lei n॰ 9.394, de 1996 - Lei de Diretrizes e Bases da Educação [Internet]. 2016 [cited 2020 Jan 6]. Available from: https://www.camara.leg.br/proposicoesWeb/fichadetramitacao?idProposicao=2085970

40. Santos LRCS, Sampaio RJ. Crise social das instituições de ensino superior e a formação em saúde para o mercado. Saúde Debate. 2017;41(spe3):277-87. doi: 10.1590/0103-11042017s321

41. Leibão MC. Conceitos do Liberalismo e Educação: indivíduo, propriedade e liberdade na Educação. Movimento Rev Educ. 2015;2(3):253272. doi: 10.22409 /mov.v0i3.266

42. Associação Brasileira de Educação a Distância-ABED. Estatuto da Associação Brasileira de Educação a Distância - ABED [Internet]. 2010 [cited 2018 Nov 4]. Available from: http://www.abed.org.br/site/pt/institucional/docs_abed/estatuto/

43. Freire P. Pedagogia da autonomia: saberes necessários à prática educativa. 25a ed. São Paulo: Terra e Paz; 1996. 
44. Garzon AMM, Silva KL, Marques RC. Liberating critical pedagogy of Paulo Freire in the scientific production of Nursing 1990-2017. Rev Bras Enferm. 2018;71(suppl 4): 1854-1861. doi: 10.1590/0034-7167-2017-0699

45. Arroyo M. Ofício de Mestre: imagens e auto-imagens. 15a ed. Cidade: Vozes; 2011.

46. Ramos FRS, Rodrigues J, Teixeira E, Backes VMS, Menegaz JC. In: Backes VMS; Menegaz JC, Moya JLM. (Orgs.). Formação Docente saúde e na enfermagem. Porto Alegre: Moriá; 2019. 295 p.

47. Leal JAL, Melo CMM. The nurses' work process in different countries: an integrative review. Rev Bras Enferm. 2018;71(2):441-52. doi: 10.1590/0034-7167-2016-0468

48. Tavares APC, Leite BS, Silveira IA, Santos TD, Brito WAP, Camacho ACLF. Analysis of Brazilian publications on distance education in nursing: integrative review. Rev Bras Enferm. 2018;71(1):214-22. doi: 10.1590/0034-7167-2016-0454

49. Lorenzetti J, Trindade LT, Pires DEP, Ramos FRS. Technology, technological innovation and health: a necessary reflection. Texto Contexto Enferm [Internet]. 2012[cited 2018 Nov 4];21(2):432-9. Available from:Available from: http://www.scielo.br/pdf/tce/v21n2/en_a23v21n2.pdf

50. Nascimento FEM, Silva DG. Educação mediada por tecnologia: inovações no processo de ensino e aprendizagem: uma revisão integrativa. Abakós. 2018;6(2):72-91. doi: 10.5752/P.2316-9451.2018v6n2p72-91 